\title{
PEMANFAATAN SAMPAH PLASTIK MENJADI PRODUK BERNILAI JUAL DENGAN MODEL TRASHION
}

\section{THE USE OF PLASTIC TRASH BECOMING A VALUABLE PRODUCT BY TRASHION MODEL}

\author{
Oleh: \\ Siti Aisyah, Sura Menda Ginting, Eka Novita, dan Khairul Amri Rosa \\ Universitas Bengkulu
}

\begin{abstract}
Trashion is the activity of turning trash into fashion goods. The utilization of waste into valuable recycled products is an activity that should be done to save the environment and income generating. This activity introduces how to process waste, designing, and making products from plastics waste. This activity invites society to make use of waste, honing skills to design and sew and look at business opportunities from Trashion products.
\end{abstract}

Keywords: Trashion, plastic waste, recycle, product design

\section{PENDAHULUAN}

Kelebihan yang dimiliki plastik dibanding bahan lainnya, membuat plastik berperan penting dalam kehidupan sehari-hari mulai dari alat rumah tangga, mainan anak-anak, aksesoris, komponen otomotif sampai dengan kemasan makanan. Ada kecenderungan peningkatan penggunaan plastik dari waktu ke waktu. Dapat dibayangkan berapa banyak limbah plastik sebagai akibat penggunaannya. Bertolak belakang dari kelebihan yang dimiliki plastik, sifat plastik yang sangat sulit terurai dalam tanah dan kandungan kimia berbahaya Bisphenol A (BPA) menimbulkan masalah yang sangat serius.

Berbagai usaha penanganan sampah plastik dilakukan oleh pemerintah (UU No. 18 tahun 2008 tentang pengelolaan Sampah Pasal 19) dan sebagian masyarakat yang sadar pentingnya lingkungan hidup melalui kegiatan $4 \mathrm{R}$ yaitu Reduce (Mengurangi), Reuse (Menggunakan kembali), Replace (Menggantikan) dan Recycle (mendaur ulang).

Kegiatan "Reduce" dapat dilakukan dengan cara membawa kantong belanja sendiri dan menolak pemberian kantong plastik dari penjual, membeli barang dalam ukuran besar dan kemasan isi ulang, bahkan mengurangi pembelian barang plastik yang tidak dibutuhkan. Menggunakan kembali botol atau kemasan plastik untuk kegiatan sehari-hari dapat dikategorikan sebagai kegiatan "reuse". Mengganti penggunaan bahan plastik dengan bahan lain yang lebih mudah diurai, seperti mengganti styrofoam dengan kertas minyak, mengganti botol minuman plastik yang mudah diremukkan dengan botol plastik keras merupakan beberapa contoh kegiatan "Replace". Sedangkan kegiatan mengubah 
sampah plastik menjadi barang yang lebih berguna dikategorikan sebagai kegiatan "Recycle".

Kegiatan recycle merupakan kegiatan yang mengubah sesuatu yang tidak lagi berguna menjadi berguna, yang lebih popular dengan nama "TRASHION". Trashion merupakan gabungan dari kata "trash" dan "fashion" yang berarti mengubah barang sampah menjadi produk untuk gaya. Pada awalnya, istilah trashion digunakan di dunia fashion yang memasukkan penggunaan produk recycle dalam kegiatan fashion-show. Pada tahun 90-an, Seniman Amerika, Anna Wizer, menggunakan sampah plastik dalam produk seni yang dapat dipakai. Kegiatan Wizer berkembang menjadi kegiatan pemberantasan kemiskinan di wilayah Asia Tenggara dengan menciptakan produk trashion aksesoris dan barang rumah tangga yang berkantor pusat di Jakarta dan diberi nama XSProject. Berikut adalah beberapa gambar produk trashion.

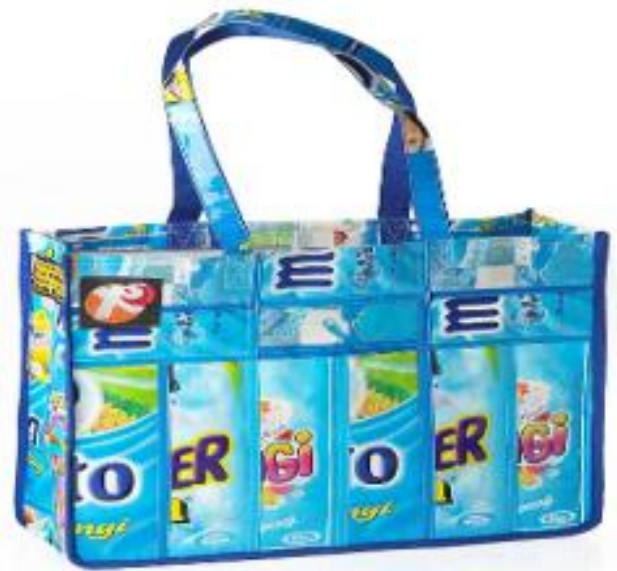

Tas belanja dari sampah kemasan pewangi pakaian

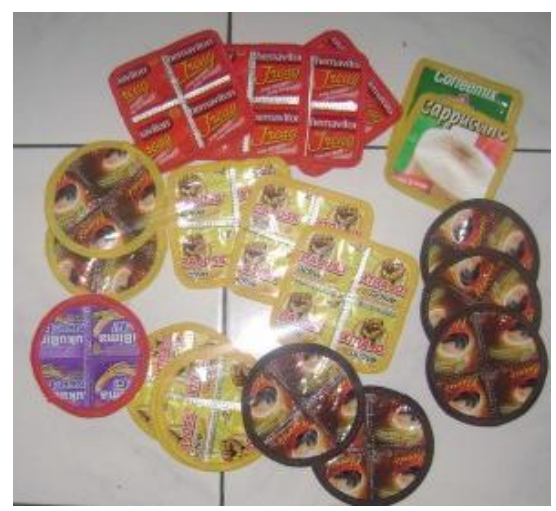

Tatakan gelas dari

Sampah bungkus minuman instan

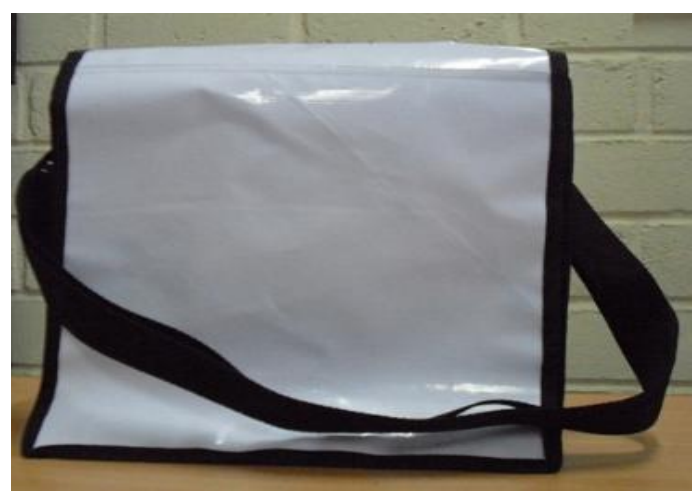

Tas belanja dari sampah spanduk

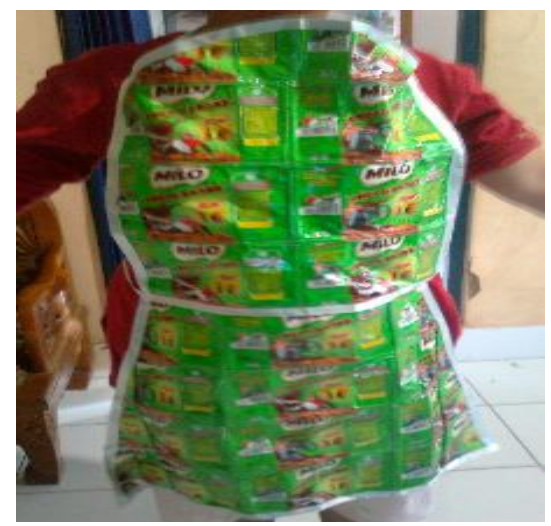

Celemek Masak/cuci piring dari sampah bungkus minuman instan

Gambar 1. Produk Trashion (Herianti, 2009) 
Saat ini, perkembangan trashion di Indonesia semakin meningkat. Berbagai usaha kecil menengah memilih untuk memanfaatkannya menjadi peluang bisnis bahkan memiliki pangsa pasar luar negeri.

Penanganan sampah di Provinsi Bengkulu merupakan masalah serius yang dihadapi oleh pemerintah dan masyarakat. Kegiatan penanganan sampah baru sebatas pengolahan sampah di tempat pembuangan sampah (TPA) dan pengumpulan barang bekas oleh pengusaha barang bekas yang menjualnya ke pengusaha atau penampung barang bekas di luar Provinsi Bengkulu. Menurut Fuadi (2013), pemerintah daerah Bengkulu harus mengubah pola pikir mengenai pengelolaan sampah, bukan hanya membuang ke TPA tapi bagaimana mengubah sampah tersebut menjadi produk yang berguna. Dalam UU No.18 Tahun 2008 pada Pasal 20 (20), pemerintah dan pemerintah daerah berkewajiban untuk memfasilitasi kegiatan daur ulang dan memfasilitasi pemasaran produk-produk daur ulang. Namun sampai saat ini, minim sekali usaha dan kegiatan penanganan sampah yang bersifat menciptakan produk trashion atau memanfaatkan sampah menjadi peluang usaha di bidang trashion Dengan demikian, dapat disimpulkan bahwa belum ada usaha pemanfaatan maksimal sampah plastik di Provinsi Bengkulu dalam kegiatan mengurangi sampah untuk menciptakan peluang bisnis berupa produk trashiom yang bernilai jual dari daur ulang sampah plastik.

Berdasarkan hasil evaluasi kegiatan Pengabdian Pada Masyarakat yang dilakukan oleh Aisyah (2012) di Desa Pulau Panggung Kecamatan Talang Empat Kabupaten Bengkulu Tengah, didapat informasi bahwa para ibu rumah tangga di desa tersebut memiliki banyak waktu luang setelah pulang dari kebun. Waktu luang ini tidak termanfaatkan dengan baik oleh mereka. Mereka sangat membutuhkan kegiatan yang bermanfaat untuk mengisi waktu luang tersebut dan berharap kegiatan itu dapat dilakukan di rumah dan menambah penghasilan keluarga. Dari hasil perbincangan dan diskusi dari beberapa ibu pengurus PKK, mereka memiliki beberapa mesin jahit dan obras yang merupakan barang bantuan dari pemerintah yang tidak termanfaatkan dengan baik dan terbengkalai.

Dari masalah-masalah yang muncul di atas, dalam rangka untuk meningkatkan keterampilan ibu rumah tangga dan memanfaatkan fasilitas mesin jahit dan obras yang tidak terpakai, maka kegiatan pelatihan pembuatan produk trashion dari sampah plastik di Desa Pulau Panggung Kecamatan Talang Empat, Kabupaten Bengkulu Tengah sangat dibutuhkan.

Ada dua tujuan utama kegiatan ini. Pertama, memberikan wawasan dan melakukan kampanye kepada masyarakat mengenai pentingnya pengelolaan sampah untuk pelestarian lingkungan hidup. Kedua adalah meningkatkan keterampilan bagi ibu rumah tangga dengan memberikan pelatihan pembuatan produk daur ulang berupa dari sampah plastic (trashion) di Desa Pulau Panggung, Kecamatan Talang Empat, Kabupaten Bengkulu Tengah. Tujuan tersebut dapat dijabarkan secara detail sebagai berikut: 
1. Memberikan pengetahuan, wawasan, dan motivasi mengenai pentingnya kegiatan pengolahan sampah dalam rangka kegiatan mengurangi penggunaan sampah plastik melalui kegiatan recycling.

2. Memberikan wawasan mengenai perilaku sehari-hari sebagai usaha mengurangi sampah.

3. Memberikan pengetahuan, wawasan, dan motivasi mengenai pentingnya memiliki keterampilan untuk memanfaatkan waktu secara baik dan alat yang mereka miliki namun tidak terpakai dan bagaimana kegiatan tersebut dapat memberikan tambahan penghasilan bagi keluarga.

4. Memberikan pengetahuan dan informasi produk daur ulang (trashion) yang banyak diminati konsumen dan dapat dijadikan peluang usaha bagi ibu rumah tangga.

5. Memberikan pengetahuan dan keterampilan praktis mengenai pembuatan produk daur ulang (trashion) dari sampah plastik.

Dari Sisi Teknis; manfaat kegiatan ini adalah;

a. Peningkatan pengetahuan mengenai kepedulian lingkungan sekitar terutama pengelolaan sampah.

b. Peningkatan pengetahuan dan wawasan para ibu rumah tangga mengenai cara pemanfaatan sampah plastik untuk kegiatan recycle.

c. Peningkatan keterampilan dalam membuat produk trashion baik dari sisi teknis pengolahan sampah plastik, seni desain dan kreatifitas, dan teknik menjahit dengan menggunakan alat jahit.

Dari Sisi Ekonomi; manfaat kegiatan ini adalah:

a. Meningkatkan pendapatan masyarakat di tempat kegiatan ini dilaksanakan melalui penciptaan produk trashion yang bernilai jual.

b. Mengurangi biaya pemerintah atau swadaya masyarakat dalam mengolah sampah.

c. Memberikan manfaat jangka panjang terhadap kelestarian lingkungan sehingga menekan biaya masa depan dalam rangka menjaga kelestarian lingkungan akibat beban sampah.

Bagi Universitas Bengkulu; manfaat kegiatan ini adalah:

a. Terlaksananya salah satu dharma dari tiga dharma perguruan tinggi yaitu dharma pengabdian kepada masyarakat sebagai salah satu peran serta Universitas Bengkulu untuk berperan aktif dalam pembangunan di Provinsi Bengkulu.

b. Sebagai media promosi tentang kepedulian lingkungan hidup kepada masyarakat laus terutama tentang kepedulian sampah dan pengelolaan sampah.

c. Mendukung dan berpartisipasi dalam penerapan UU No. 8 Tahun 2008 tentang Pengelolaan Sampah. 


\section{METODE PENGABDIAN}

Berikut adalah matriks masalah, tujuan, alternatif pemecahan masalah kegiatan pengabdian ini.

\begin{tabular}{|c|c|c|}
\hline Masalah & Alternatif Pemecahan Masalah & $\begin{array}{c}\text { Pemecahan Masalah yang } \\
\text { Dipilih }\end{array}$ \\
\hline $\begin{array}{l}\text { Belum ada kegiatan } \\
\text { pengolahan sampah } \\
\text { plastik }\end{array}$ & $\begin{array}{l}\text { 1. Diserahkan kepada pemerintah } \\
\text { dalam bentuk pengolahan } \\
\text { sampah akhir } \\
\text { 2. Diserahkan kepada pengusaha } \\
\text { pengepul sampah } \\
\text { 3. Melibatkan masyarakat dalam } \\
\text { pengolahan sampah plastik } \\
\text { melalui kegiatan recycling }\end{array}$ & $\begin{array}{l}\text { Melibatkan masyarakat } \\
\text { dalam pengolahan sampah } \\
\text { plastik melalui kegiatan } \\
\text { recycling }\end{array}$ \\
\hline
\end{tabular}

\section{Alasan:}

Pemecahan masalah ini dipilih karena pengolahan sampah plastik lebih efektif melibatkan masyarakat melalui kegiatan mengurangi dan menggunakan kembali

$\begin{array}{lr}\text { Waktu luang para } & \text { 1. Diisi dengan berbagai kegiatan } \\ \text { ibu rumah tangga di } & \text { rumah tangga } \\ \text { Desa Pulau } & \text { 2. Diisi dengan melakukan hoby } \\ \text { Panggung, Kec. } & \text { masing-masing } \\ \text { Talang Empat, } & \text { 3. Diisi dengan kegiatan } \\ \text { Kabupaten Benteng } & \begin{array}{l}\text { bermafaat dan dapat } \\ \text { menambah penghasilan }\end{array}\end{array}$

\section{Alasan:}

Pemanfaatan waktu luang sebaiknya merupakan kegiatan ekonomis yang menambah penghasilan ditengah sulitnya memperoleh tambahan untuk meningkatkan penghasilan keluarga

\begin{tabular}{lr}
\hline $\begin{array}{l}\text { Peralatan jahit } \\
\text { menjahit bantuan }\end{array}$ & $\begin{array}{l}\text { Disewakan kepada pihak yang } \\
\text { membutuhkan }\end{array}$ \\
$\begin{array}{l}\text { pemerintah yang } \\
\text { tidak termanfaatkan } \\
\text { dengan baik dan }\end{array}$ & 2. Digunakan dalam kegiatan \\
masyarakat \\
terbengkalai.
\end{tabular}

Diisi dengan kegiatan bermafaat dan dapat menambah penghasilan

\section{Alasan:}

Pengadaan bantuan peralatan oleh pemerintah bertujuan untuk meningkatkan keterampilan masyarakat yang sesuai dengan tujuan pengadaan alat tersebut 


\section{Khalayak Sasaran}

Khalayak sasaran kegiatan ini adalah masyarakat Desa Pulau Panggung, Kecamatan Talang Empat, khususnya ibu-ibu rumah tangga dan remaja putri yang tertarik untuk meningkatkan keterampilan yang dimiliki terutama bagi mereka yang belum memiliki pekerjaan. Beberapa ibu rumah tangga di desa tersebut ada yang memiliki keahlian jahit menjahit dan organisasi PKK desa tersebut memiliki alat jahit yang tidak digunakan secara maksimal. Dengan demikian, khalayak sasaran mendukung karakteristik kegiatan ini yang membutuhkan beberapa peserta yang memiliki keahlian jahit menjahit dan adanya alat jahit.

Kegiatan ini diterapkan melalui metode campuran antara ceramah, pelatihan, dan pameran. Kegiatan dibagi dalam 3 sub kegiatan yaitu:

a. Ceramah Mengenai sampah dan pengelolaannya; ceramah dilakukan pada awal pelaksanaan kegiatan. Ceramah tersebut secara tidak langsung berupaya untuk mengubah pola pikir masyarakat mengenai sampah.

- Menggali informasi sejauh mana pengetahuan sampah dan pengolahannya.

- Menggali informasi mengenai perilaku peserta sehari-hari dalam menangani sampah.

- Memulai ceramah mengenai pengolahan sampah berdasarkan tingkat pengetahuan peserta.

- Memberikan contoh-contoh sikap dan perilaku sehari-hari yang seharusnya dilakukan terhadap sampah dan pengelolaannya.

- Memotivasi peserta dengan berdiskusi mengenai ide dan kreasi mereka mengenai pemanfaatan sampah.

- .Memperkenalkan trashion sebagai salah satu kegiatan daur ulang sampah.

- Memperlihatkan/mendisplay produk-produk trashion yang sudah dipersiapkan terlebih dahulu.

- Memberikan beberapa buku mengenai pengolahan sampa plastik menjadi produk trashion.

- Memberikan kesempatan bagi peserta untuk berdiskusi mengenai apa saja yang harus dilakukan pada pelatihan dan kegiatan pameran produk mereka dan bagaimana mereka mengkolaborasikan tingkat keahlian mereka untuk mencapai tujuan karena tentunya peserta ada yang memiliki keahlian jahit menjahit dan tidak.

b. Pelatihan Pembuatan produk trashion; Ada dua pelatihan yang akan dilaksanakan dan dalam waktu yang berbeda.

\section{Pelatihan Desain Produk Trashion}

- Melatih bagaimana mendesain produk trashion dari bahan sampah plastik yang telah dipilih. 
- Memperagakan contoh produk dan bagaimana mendesain polanya dan mendesain rangkaian bahan sampah plastik yang dipilih

- Melatih mendesain produk yang telah dipilih untuk pelatihan

- Memberikan kesempatan bagi peserta untuk mendesain produk dan polanya sesuai ide mereka masing-masing.

2. Pelatihan Menjahit dan Finishing Produk Trashion; Pelatihan ini merupakan lanjutan kegiatan desain produk trashion.

- Memperagakan kepada peserta bagaimana menjahit produk trashion. Kegiatan ini juga bisa dilakukan dengan meminta kesediaan beberapa peserta yang memiliki keterampilan menjahit untuk membantu tim pengabdian.

- Memperagakan kepada peserta bagaimana memberikan sentuhan seni dalam tahap finishing produk trashion.

Catatan: Pelatihan ini akan dilanjutkan di rumah masing-masing untuk memenuhi kebutuhan produk untuk kegiatan pameran. Salah satu peserta ditunjuk sebagai seorang quality control produk trashion.

c. Pameran Produk Trashion; Kegiatan ini bertujuan untuk mempromosikan produk trashion kepada masyarakat kampus Universitas Bengkulu atau di Pusat Perbelanjaan (Jika memungkinkan).

- Mengikutsertakan beberapa orang peserta dalam kegiatan pengajuan proposal kegiatan produk trashion kepada masyarakat kampus Universits Bengkulu bekerja sama dengan LPPM Unib (Pusat Perbelanjaan).

- Mempersiapkan beberapa peserta sebagai penjaga stand dengan memberikan pengetahuan bagaimana menjelaskan mengenai produk trashion dan hubungannya dengan pengelolaan sampah.

- Mengikutsertakan beberapa peserta dalam merencanakan display produk trashion.

- Membagikan flyer mengenai kegiatan daur ulang dan produk trashion kepada pengunjung.

\section{Keterkaitan}

Kegiatan ini memiliki keterkaitan dengan pihak:

1. Pemerintah Daerah Kabupaten Bengkulu Tengah, Kegiatan ini membantu meringankan tugas dan kewajiban yang seharusnya di lakukan oleh pemerintah daerah Kabupaten Bengkulu Tengah dalam melaksanakan UU No. 18 Tahun 2008 mengenai Pengelolan Sampah.

2. Para produsen produk yang menggunakan plastik sebagai kemasan produk; Kegiatan ini secara langsung membantu produsen melaksanakan UU No. 18 Tahun 2008 Pasal 15 yang mewajibkan produsen mengelola kemasan yang sulit terurai oleh proses alam. 
3. Universitas Bengkulu, sebagai lembaga yang membina desa binaan dan harus selalu melaksanakan dan mewujudkan Tridharma Perguruan Tinggi untuk kemakmuran masyarakat.

\section{HASIL DAN PEMBAHASAN}

\section{Deskripsi Kegiatan}

Kegiatan ini dilakukan dalam 2 tahap yaitu kegiatan ceramah dan Pelatihan 1 pada tanggal 21 Oktober 2013, dan kegiatan pelatihan 2 pada tanggal 11 November 2013. Semua kegiatan dilakukan pada hari senen karena masyarakat di desa sasaran hanya libur dan berada di rumah pada hari tersebut di rumah salah satu anggota masyarakat desa yang bersedia rumahnya dijadikan tempat kegiatan.

Sebelum kegiatan utama dimulai, tim telah melakukan kunjungan awal pada tanggal 7 Oktober 2013 untuk mengecek keadaan mesin jahit sebagai alat kegiatan. Ada 2 mesin jahit yang diperbaiki. Kegiatan pada tanggal 21 Oktober 2013 diikuti oleh 15 peserta ibuibu dan remaja putri, sedangkan pada kegiatan pada tanggal 11 November 2013 diikuti oleh 12 peserta saja. Untuk Kegiatan pameran produk sesuai rencana kegiatan tidak dapat dilaksanakan karena keterbatasan waktu.

\section{Hasil Kegiatan}

1. Ceramah: Sampah dan Pengelolaannya

Kegiatan ini diawali dengan menayangkan video mengenai sampah dan pengelolaannya dalam bentuk produk bernilai jual tinggi dan dapat dimanfaatkan untuk kehidupan pribadi dan bisnis. Kegiatan dilanjutkan dengan menggali respon peserta mengenai video yang ditayangkan menyangkut sampah dan kehidupan manusia, sampah dan produk olahannya. Dari hasil pengamatan atas diskusi terlihat bahwa banyak masyarakat yang masih belum menyadari perilaku membuang sampah mereka dan sebagian menganggap sampah adalah sesuatu yang kotor yang tidak selayaknya memasuki kehidupan mereka dalam bentuk produk yang dapat digunakan oleh mereka kembali (recycle). Setelah diberikan penjelasan bagaimana dampak sampah jika tidak diolah menjadi produk berguna dan bagaimana gerakan masyarakat di belahan bumi lain, mereka mulai menyadari bahwa sampah tidaklah selamanya menjadi sampah, namun dapat menjadi produk yang berguna.

\section{Pelatihan I: Pelatihan Desain Produk Trashion}

Setelah kegiatan ceramah, diskusi dan penayangan video, kegiatan dilanjutkan dengan memperlihatkan beberapa produk "trashion". Peserta diminta mengamati, lalu berkreasi sesuai dengan ide masing-masing atas sebuah produk yang ingin mereka buat. Peserta diberi kertas dan alat tulis untuk menuangkan ide masing-masing. Dari gambar tersebut, peserta diminta untuk memikirkan bahan apa yang akan digunakan untuk kreasi 
tersebut. Setelah mereka memutuskan bahan sampah apa yang akan digunakan dan bahan pendukung lainnya, maka peserta diajarkan untuk membuat pola atas rencana produk tersebut. Beberapa peserta cukup lancer dalam mendesain dan menentukan bahan sampah apa yang akan digunakan. Hampir seluruh peserta mendesain tas belanja ke pasar. Hal ini dapat dipahami karena tas belanja merupakan produk yang paling sering digunakan ibu-ibu dan remaja putri dan mereka memerlukan tas yang murah dan kuat untuk mengangkat beban belanja yang berat. Di akhir kegiatan ini, peserta diminta untuk menyiapkan bahan produk dari sampah yang mereka kumpulkan dari sekitar rumah dan lingkungan mereka dan diolah menurut keterangan yang diberikan pemateri.

\section{Pelatihan II: Pelatihan Menjahit dan Finishing Produk Trashion}

Pada kegiatan ini, bahan-bahan yang telah disiapkan oleh peserta digunting sesuai pola desain yang dipilih dan dilakukan penyambungan dan penyelesaian dengan menggunakan mesin jahit. Ada beberapa produk yang dirancang tidak menggunakan mesin jahit, hanya menggunakan lem lilin panas karena memang desainnya tidak membutuhkan alat jahit.

\section{Pameran Produk Trashion}

Kegiatan ini tidak dapat dilaksanakan karena keterbatasan waktu peserta.

\section{KESIMPULAN DAN SARAN}

\section{KESIMPULAN}

Kegiatan mendatangkan banyak manfaat dan pengetahuan bagi peserta khalayak sasaran. Khalayak sasaran yang sebelumnya tidak tahu menjadi tahu. Hal ini tentu saja menjadi motivasi tersendiri bagi mereka yang belum tahu, kemudian menjadi tahu bahwa ada manfaat sampah, terutama secara ekonomi.

Kesadaran masyarakat tentang pemanfaatan sampah menjadi produk yang berguna belum begitu tinggi. Hal ini dapat dilihat bagaimana masyarakat memandang produk yang berbahan sampah. Kegiatan sosialisasi pemanfaatan sampah harus terus ditingkatkan.

\section{SARAN}

Untuk keberhasilan kegiatan ini dimasa depan, maka:

1. Kegiatan ini harus dilanjutkan pada kelompok masyakat lain terutama masyarakat perkotaan.

2. Bekerja sama dengan pengusaha untuk mendukung kegiatan lebih lanjut dan memasarkan produk trashion. 


\section{DAFTAR PUSTAKA}

Aisyah, Siti, 2012, Pelatihan Pembuatan produk Aksesoris Berbahan Kain Untuk Menumbuhkan Jiwa Entrepreneur Masyarakat Dewa Pulau Panggung Kecamatan Talang Empat Kabupaten Bengkulu Tengah. Laporan Hasil Kegiatan PPM Universitas Bengkulu.

Anonim. UU No. 18 tahun 2008 tentang Pengelolaan Sampah.

Fuadi, Hilman, 2013, Paradigma Baru Penanganan Sampah Perkotaan. Diunduh pada tanggal 22 Maret 2013, pukul 09.59 WIB melalui http://www.bengkulukota.go.id/v2/sermon/paradigman-baru-penanganan-sampahperkotaan/.

Herianti, 2009, From Trash to Fashion: 25 Kreasi Limbah Plastik. Gramedia Pustaka Utama. Jakarta. 


\section{Evaluasi Kegiatan}

Evaluasi kegiatan dilakukan berdasarkan rancangan evalusi kegiatan. Evaluasi kegiatan adalah sebagai berikut:

\section{Tabel 10. Evaluasi Kegiatan}

\begin{tabular}{|c|c|c|c|c|c|c|}
\hline Kegiatan & Tujuan & Kriteria Evaluasi & Indikator & Tolok Ukur & Realisasi & Pencapaian \\
\hline \multirow{10}{*}{$\begin{array}{l}\text { Ceramah: } \\
\text { Sampah dan } \\
\text { Pengelolaann } \\
\text { ya }\end{array}$} & - Memberikan pengetahuan, wawasan, & - Peserta yang hadir pada & Kehadiran & $>50 \%$ & 20 undangan, & $75 \%$ \\
\hline & dan motivasi mengenai sampah dan & kegiatan ceramah & & & hadir 15 & \\
\hline & pentingnya pengelolaan sampah untuk & dibandingkan dengan & & & undangan & \\
\hline & kelestarian lingkungan hidup. & jumlah peserta yang & & & & \\
\hline & & diundang & & & & \\
\hline & - Memperkenalkan "Trashion" untuk & - Peserta bertanya dan & Antusiasme & $>50 \%$ & 10 orang & $75 \%$ \\
\hline & meningkatkan perekonomian keluarga, & memberikan tanggapan & bertanya & & bertanya & \\
\hline & masyarakat sekitar dan dampak jangka & & & & & \\
\hline & panjang terhadap perekonomian & & & & & \\
\hline & Kabupaten Bengkulu Tengah. & & & & & \\
\hline \multirow{10}{*}{$\begin{array}{l}\text { Pelatihan I: } \\
\text { Pelatihan } \\
\text { Desain } \\
\text { Produk } \\
\text { Trashion }\end{array}$} & - Memberikan pengetahuan dan & - Peserta yang hadir & Kehadiran & $>50 \%$ & 20 undangan, & $60 \%$ \\
\hline & keterampilan praktis bagaimana & & & & hadir 12 & \\
\hline & mendesain suatu produk dengan bahan & & & & undangan & \\
\hline & dasar dari sampah limbah plastik yang & - Peserta yang bertanya dan & Antusiasme & $>30 \%$ & undangan & $100 \%$ \\
\hline & telah dipilih & menjawab & Bertanya & & bertanya dan & \\
\hline & & & & & berkomentar & \\
\hline & & - Peserta yang bersedia & Dapat & Min $30 \% \mathrm{dr}$ & 12 bersedia & $100 \%$ \\
\hline & & mencoba membuat pola & Membuat & peserta & & \\
\hline & & dari produk trashion yang & & & & \\
\hline & & menjadi contoh dari tim & & & & \\
\hline
\end{tabular}


- Desain produk trashion Jumlah $\quad$ Min 3 desain 12 Desain $\quad 100 \%$ baru yang berbeda dengan Desain produk contoh

\begin{tabular}{|c|c|c|c|c|c|c|}
\hline $\begin{array}{l}\text { Pelatihan II: } \\
\text { Pelatihan } \\
\text { Menjahit dan } \\
\text { Finishing } \\
\text { Produk } \\
\text { Trashion }\end{array}$ & $\begin{array}{l}\text { - Memberikan keterampilan praktis } \\
\text { bagaimana menjahit suatu produk } \\
\text { dengan bahan dasar dari sampah limbah } \\
\text { plastik yang telah dipilih } \\
\text { - Memberiakan keterampilan praktis } \\
\text { bagaimana memberikan sentuhan akhir } \\
\text { (finishing) yang bernilai seni untuk } \\
\text { meningkatkan nilai jual produk trashion }\end{array}$ & $\begin{array}{l}\text { - Produk trashion yang } \\
\text { selesai dikerjakan }\end{array}$ & $\begin{array}{l}\text { Jumlah } \\
\text { Produk }\end{array}$ & $\begin{array}{l}>30 \% \text { desain } \\
\text { awal }\end{array}$ & 5 produk & $41 \%$ \\
\hline $\begin{array}{l}\text { Pameran } \\
\text { Produk } \\
\text { Trashion }\end{array}$ & $\begin{array}{l}\text { - Mempromosikan kegiatan pengolahan } \\
\text { sampah plastik (trashion) } \\
\text { - Mempromosikan produk trashion dari } \\
\text { hasil kegiatan }\end{array}$ & $\begin{array}{l}\text { - Flyer yang dibagikan } \\
\text { - Pengunjung yang } \\
\text { mengunjungi stand } \\
\text { pameran } \\
\text { - Produk trashion yang } \\
\text { terjual }\end{array}$ & $\begin{array}{l}\text { Jumlah } \\
\text { Flyer } \\
\text { Jumlah } \\
\text { Pengunjung } \\
\text { Jumlah } \\
\text { Produk } \\
\text { Terjual }\end{array}$ & $\begin{array}{l}75 \% \\
50 \text { orang } \\
\\
50 \% \quad \text { dari } \\
\text { produk display }\end{array}$ & 0 & 0 \\
\hline
\end{tabular}

